KREATIF : Jurnal Ilmiah Prodi Manajemen Universitas Pamulang, Vol. 8, No.2, Desember 2020

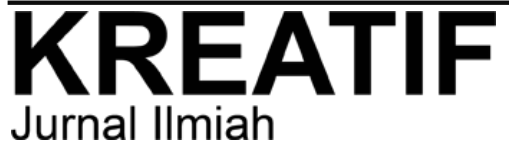

Jurnal IImiah
@ Prodi Manajemen Fakultas Ekonomi Universitas Pamulang

ISSN : 2339 - 0689, E-ISSN : 2406-8616

J. KREATIF, Vol. 8 No.2, Desember 2020 (Halaman 57-66)

Tersedia Online di :http://openjournal.unpam.ac.id/index.php/kreatif

\title{
PENGARUH DISIPLIN KERJA, INSENTIF, KOMUNIKASI DAN LINGKUNGAN KERJA FISIK TERHADAP KINERJA KARYAWAN PADA PT GANDA SARIBU UTAMA
}

\author{
Muhammad Faqih Maulana ${ }^{1}$,Demak Claudia Yosephine Simanjuntak ${ }^{2}$, Robin $^{3}$ \\ ${ }^{1-3}$ Universitas Prima Indonesia - Sumatera Utara \\ email: claudiayoseph8@gmail.com
}

\begin{abstract}
ABSTRAK
Pengujian serta analisa dampak disiplin kerja, insentif, komunikasi, serta lingkungan kerja fisik pada kinerja karyawan PT. Ganda Saribu Utama baik secara mandiri dan bersamasama merupakan tutujuan dari penelitian ini. Penelitian berjenis deskriptif kuantitatif, dengan sifat explanatory. 128 orang karyawan pada PT. Ganda Saribu Utama dijadikan populasi dalam penelitian. Sampel 97 orang yang didapat dengan memakai rumus Slovin. Teknik wawancara, kuesioner dan studi dokumentasi dilakukan untuk mendapatkan data penelitian. Metode analisis data secara regresi linier berganda, uji koefisien determinasi, uji parsial dan uji simultan. Hasilnya disiplin kerja, insentif, komunikasi, serta lingkungan kerja fisik dengan mandiri serta bersamaan mempengaruhi kinerja karyawan PT. Ganda Saribu Utama. $82,6 \%$ berdasarkan variasi variabel terikat kinerja karyawan yang bisa ditegaskan dengan variabel bebas disiplin kerja, insentif, komunikasi dan lingkungan kerja fisik, 17,4\% sisa uji koefisiens determinasi ditegaskan selain variabel penelitian.

Kata Kunci : Disiplin Kerja, Insentif, Komunikasi, Dan Lingkungan Kerja Fisik Dan Kinerja Karyawan
\end{abstract}

\begin{abstract}
Testing and analyzing the impact of work discipline, incentives, communication, and physical work environment on the performance of employees of PT. Ganda Saribu Utama both independently and collectively is the aim of this research. This type of research is descriptive quantitative, with explanatory nature. 128 employees at PT. Ganda Saribu Utama was the population in the study. The sample of 97 people was obtained using the Slovin formula. Interview techniques, questionnaires, and documentation studies were conducted to obtain research data. Methods of data analysis using multiple linear regression, coefficient of determination test, partial test, and simultaneous test. The result is work discipline, incentives, communication, and the physical work environment independently and simultaneously affecting the performance of PT. Ganda Saribu Utama. $82.6 \%$ based on variations in the dependent variable of employee performance which can be emphasized by the independent variables of work discipline, incentives, communication, and physical work environment, 17.4\% of the rest of the coefficient of determination test is confirmed in addition to research variables.
\end{abstract}

Keywords : Work Discipline, Incentives, Communication, And Physical Work Environment And Employee Performance

\section{PENDAHULUAN}


KREATIF : Jurnal Ilmiah Prodi Manajemen Universitas Pamulang, Vol. 8, No.2, Desember 2020

\section{A. Latar Belakang Masalah}

Persoalan kinerja berhubungan dengan tahapan hasil serta efektivitas, terkait hal ini kinerja merupakan hasil kerja berkaitan dengan mutu serta jumlah yang diraih seorang karyawan dalam menjalankan pekerjaannya berdasarkan tanggung jawab yang dibebankan. PT. Ganda Saribu Utama adalah perusahaan yang beroperasi disektor industri enamelware, dan plasticware, dan kompor dengan merek Royal, Panen, GSU dan Mahoni. Hasil survey awal didapatkan informasi melemahnya kinerja pegawai yang diketahui dari omzet yang mengalami fluktuasi.

Disiplin kerja dijelaskan sebagai sikap sadar serta kesiapan individu untuk mematuhi seluruh aturan perusahaan dan hukum yang berjalan. Permasalahan ketaatan kerja di perusahaan yaitu kurangnya pengawasan dari pimpinan berdampak pada karyawan yang kurang patuh pada aturan yang ditetapkan perusahaan, datang terlambat, tidak berada ditempat pada saat jam kerja.

Pemberian insentif juga menjadi penyemangat bagi karyawan untuk dapat lebih meningkatkan kinerjanya. Permasalahan insentif yang terjadi di perusahaan yaitu tingkat pemberian insentif tidak merata, perbedaan ini menjadi penyebab karyawan bermalasan untuk meningkatkan kinerjanya.

Jalinan komunikasi yang terbina antar karyawan, karyawan dengan atasan diperlukan dalam upaya kinerja yang lebih maksimal. Komunikasi menjadi penghubung atasan dengan anggota organisasi, atau anggota dengan anggota dalam pencapaian tujuan. Persoalan yang berhubungan dengan komunikasi yang menjadi penyebab kinerja karyawan tidak sesuai dengan harapan yaitu komunikasi yang berlangsung tidak berjalan mulus. Hal ini berimbas pada kesalahan menanggapi setiap pesan disampaikan.

Selain disiplin, insentif, dan komunikasi, ketenangan dan kedamaian lingkungan kerja fisik sangat mempengaruhi kinerja karyawan. Kenyamanan lingkungan kerja fisik diharapkan menimbulkan semangat baru dalam bekerja, sehingga kemauan atau semangat kerja tenaga kerja berjalan sesuai dengan keinginan dan harapan perusahaan. Permasalahan lokasi kerja di sekitar tenaga kerja yaitu tempat atau ruang kerja kurang nyaman, bising, sirkulasi udara di dalam ruangan kerja yang tidak cocok dengan jumlah karyawan, ruangan kerja yang terasa panas meskipun dilengkapi fasilitas pendingin ruangan.

Uraian masalah tersebut dijadikan peneliti untuk mengetahui lebih mendalam faktor yang berkaitan dengan kinerja karyawan dengan memilih judul penelitian "Pengaruh Disiplin Kerja, Insentif, Komunikasi dan Lingkungan Kerja Fisik Terhadap Kinerja Karyawan Pada PT. Ganda Saribu Utama".

\section{B. Rumuan Masalah}

1. Bagaimana pegaruh Disiplin Kerja terhadap Kinerja Karyawan PT. Ganda Saribu Utama Medan

2. Bgaiamana pengaruh Insentif terhadap Kinerja Karyawan PT. Ganda Saribu Utama Medan

3. Bgaimana pengarh Komunikasi terhadap Kinerja Karyawan PT. Ganda Saribu Utama Medan

4. Bgaimana pengaruh Lingkungan Kerja Fisik terhadap Kinerja Karyawan PT. Ganda Saribu Utama Medan

5. Bgaimana Pengaruh Disiplin Kerja, Insentif, Komunikasi serta Lingkungan Kerja Fisik memberikan pengaruh secara serempak terhadap Kinerja Karyawan PT. Ganda Saribu Utama Medan. 
KREATIF : Jurnal Ilmiah Prodi Manajemen Universitas Pamulang, Vol. 8, No.2, Desember 2020

\section{TINJAUAN PUSTAKA}

\section{A. Disiplin Kerja}

Disiplin merupakan usaha pihak manajemen untuk mendorong anggota organisasi mematuhi peraturan yang telah ditentukan, Siagian (2015: 305). Indikator yang menjadi ukuran kadar kedisiplinan pegawai dalam organisasi yaitu: tujuan, serta kompetensi, panutan atasan, penghargaan, keadilan, waskat, sanksi hukuman, kejelasan, dan rasa kemanusiaan, Hasibuan (2016:194).

\section{B. Insentif}

Insentif merupakan hadiah berupa uang yang dialokasikan pimpinan organisasi untuk pegawai supaya bisa bekerja lebih bergairah, dan berprestasi dalam meraih misi organisasi, Mangkunegara (2013:89). Insentif adalah pemberian tambahan gaji sebagai penghargaan, serta menaikkan semangat pegawai bekerja, dan kinerjanya yang sukses, Widodo (2014:161). Macam-macam bentuk pemberian insentif, yaitu: hadiah untuk pegawai yang sukses meraih misi organisasi, hadiah bagi pegawai berkeahlian, hadiah atas penilaian kinerja, dan tambahan bagi pegawai yang selesai mengikuti pelatihan, Wibowo (2014:301),

\section{Komunikasi}

Tahap penyaluran amanat pesan dari pengirim (sender) untuk penerima (receiver atau audience) merupakan pengertian komunikasi yang dikutip dari Sumarsan (2013:24). Menurut Afandi (2016:50), indikator komunikasi ialah: bijaksana, kesopanan, kata yang tepat, bahasa yang sopan, dan halus.

\section{Lingkungan Kerja Fisik}

Lingkungan pekerjaan adalah seluruh fasilitas serta infrastruktur kerja yang berada disekeliling pegawai yang tengah menjalankan tugasnya yang bisa memengaruhi berjalannya pekerjaan, Sutrisno (2011:118). Segala hal yang dapat menjelaskan keadaan lokasi tempat pekerja bekerja terkait dengan kecakapan pegawai, diantaranya adalah : sirkulasi udara, kebisingan, suhu udara, keamanan dan bau-bauan, Sedarmayanti (2011:28-33).

\section{E. Kinerja}

Keberhasilan seorang karyawan dalam mengerjakan pekerjaan dengan kecakapan, daya upaya, dan harapan disebut juga dengan prestasi kerja, Hasibuan (2016:160). Peningkatan prestasi kerja dapat dilakukan dengan menggunakan dimensi: total pekerjaan, mutu pekerjaan, disiplin, tingkat absensi, dan kecakapan kolaborasi, Bangun (2012: 234).

\section{F. Teori Pengaruh Disiplin Terhadap Kinerja Karyawan}

Persoalan disiplin karyawan yang ada di dalam perusahaan antara atasan dengan bawahan, ataupun antara sesama karyawan memberi warna bagi prestasi organisasi. Jika setiap karyawan dan seluruh anggota organisasi meningkatkan prestasi kerjanya, maka prestasi kerja organisasi akan diperoleh. Gagasan dan ide seluruh karyawan dibutuhkan untuk pencapaian prestasi kerja tersebut, Sutrisno (2013:177).

\section{G. Teori Pengaruh Insentif Terhadap Kinerja Karyawan}

Salah satu perangsang karyawan dalam meningkatkan prestasi kerja dan daya kreativitas karyawan adalah insentif, Yuniarsih, dan Suwatno (2016:127),

\section{H. Teori Pengaruh Komunikasi Terhadap Kinerja Karyawan}


KREATIF : Jurnal Ilmiah Prodi Manajemen Universitas Pamulang, Vol. 8, No.2, Desember 2020

Robbins, dan Judge (2014:79) menyatakan, hal terbesar yang menghalangi prestasi kerja seluruh anggota organisasi adalah proses komunikasi yang tidak berjalan dengan lancar.

\section{Teori Pengaruh Lingkungan Kerja Fisik Terhadap Kinerja Karyawan}

Lokasi bekerja yang layak, bersih, tidak gelap (cukup sinar), terhindar dari keributan, dan gangguan, pasti akan menjadi penyemangat untuk karyawan dalam melakukan aktivitas atau pekerjaan dengan baik. Sebaliknya tempat karyawan bekerja yang berserakan, kumuh, gelap, pengab, lembab, serta sejenisnya, akan menimbulkan cepat lelah, dan menurunkan kekuatan produktivitas. Untuk itu peran pimpinan organisasi yang inovatif diharapkan mampu membuat lokasi atau tempat karyawan bekerja menjadi nyaman bagi karyawan, Kadarisman (2013: 301).

\section{J. Kerangka Konseptual}

Dari penjelasan tesebut, bisa dirancang suatu kerangka konseptual ini:

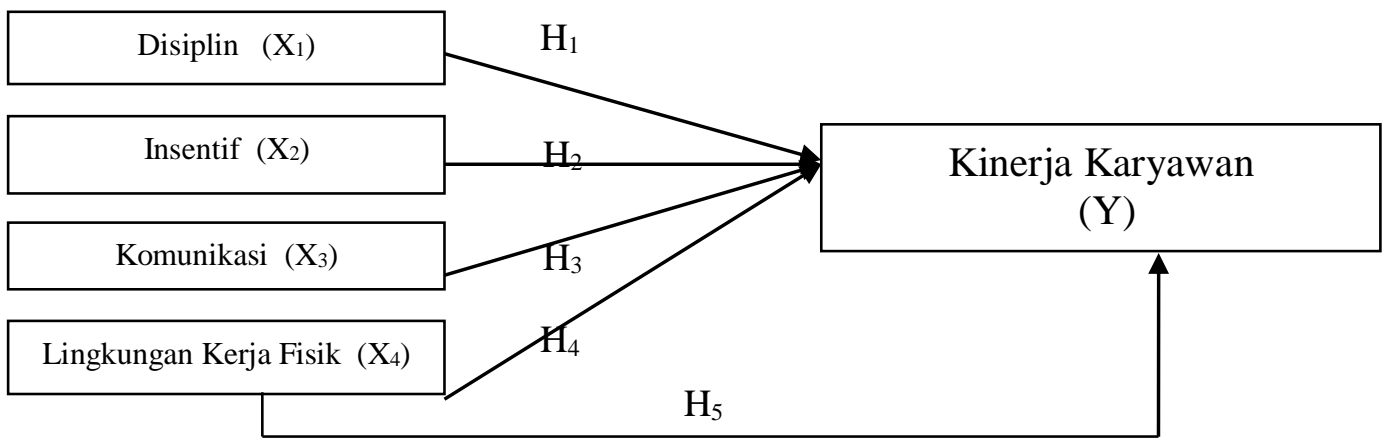

\section{K. Hipotesis Penelitian}

\section{Gambar II.1 Kerangka Konseptual}

Hipotesis merupakan kebenaran sementara terhadap suatu permasalahan yang ingin diteliti, diuraikan dalam bentuk kalimat pertanyaan, Sugiyono (2017:99). Berikut hipotesis penelitian ini adalah

$\mathrm{H}_{0} \quad$ : Diduga disiplin kerja, insentif, komunikasi, dan lingkungan kerja fisik tidak berpengaruh terhadap kinerja karyawan PT. Ganda Saribu Utama Medan.

$\mathrm{H}_{\mathrm{a}} \quad$ : Diduga disiplin kerja, insentif, komunikasi, dan lingkungan kerja fisik berpengaruh secara parsial dan simultan terhadap kinerja karyawan PT. Ganda Saribu Utama Medan

\section{METODE PENELITIAN}

\section{A. Jenis Penelitian}

Penelitian ini berjenis deskriptif kuantitatif. Penelitian deskriptif kuantitatif merupakan skema penelitian yang dirancang sebagai upaya menyampaikan prediksi yang terstruktur mengenadi data ilmiah yang sumbernya dari subjek/objek penelitian,Salim dan Haidir (2019:45).

\section{B. Sifat Penelitian}

Deskriptif eksplanatory adalah sifat dari penelitian ini. Explanatory research adalah penelitian dengan tujuan mengkaji keterkaitan antar variabel yang menguraikan suatu fenomena tertentu, Zulganef (2013:11). Dalam penelitian explanatory. peneliti berupaya untuk menguraikan serta memperlihatkan korelasi serta dampak diantara variabel.

\section{Populasi, dan Sampel}


KREATIF : Jurnal Ilmiah Prodi Manajemen Universitas Pamulang, Vol. 8, No.2, Desember 2020

Yang menjadi subjek dalam penelitian ini adalah seluruh pegawai PT. Ganda Saribu Utama yang totalnya 128 orang. 97 orang karyawan PT. Ganda Saribu Utama yang ditetapkan sebagai sampel didapat dengan menggunakan rumus slovin.

D. Teknik Pengumpulan Data

Pengumpulan datanya menggunakan teknik interview, angket, dan studi dokumentasi, Sanusi (2011:105-114),

\section{E. Uji Validitas, dan Reliabilitas Instrumen Variabel}

\section{Uji Validitas Instrumen Variabel Penelitian}

Digunakan untuk menilai kecermatan dan ketepatan data. Berdasarkan hasil uji validitas instrument diperoleh hasil koefisien korelasi diatas 0,361 serta diperkuat hasil signifikansi $(2-$ tailed $)$ semua instrument dibawah angka $\alpha$ yaitu 0,05 sehingga disimpulkan seluruh butir pertanyaan sudah valid, dan dapat dipakai untuk penelitian

\section{Uji Reliabilitas Instrumen Variabel}

Bermanfaat dalam menentukan apakah instrumen angket yang bisa di pakai berkalikali, minimal adalah indeks yang menunjukkan sejauhmana suatu alat ukur dapat diandalkan atau diyakini kebenarannya. Metode uji reliabilitattts yang sering digunakan adalah Cronbach's Alpha, Sufren dan Natanael (2014:53)

\section{F. Uji Asumsi Klasik}

Pemakaian model analisis regresi dalam statistik harus bebas dari asumsi-asumsi klasik. Adapun pengujian asumsi klasik yang digunakan dalam penelitian ini adalah uji normalitas, uji multikolinearitas, dan uji heteroskedatisitas.

\section{G. Model Analisis Data Penelitian}

Penelitian memakai model analisis regresi linier berganda yang berguna untuk melihat dampak variabel bebas pada variabel terikat yang menggunakan rumus berikut :

$$
\mathrm{Y}=\mathrm{a}+\mathrm{b}_{1} \mathrm{X}_{1}+\mathrm{b}_{2} \mathrm{X}_{2}+\mathrm{b}_{3} \mathrm{X}_{3}+\mathrm{b}_{4} \mathrm{X}_{4}+\mathrm{e}
$$

Alat uji hipotesis yang dipakai untuk menguji apakah uji diterima atau ditolak adalah uji parsial, uji simultan, serta uji determinasi yang berguna dalam melihat kekuatan variabel independen menguraikankan variabel terikat.

\section{HASIL PENELITIAN DAN PEMBAHASAN}

\section{A. Hasil Uji Asumsi Klasik}

\section{Uji Normalitas}

\subsection{Analisa Grafik}
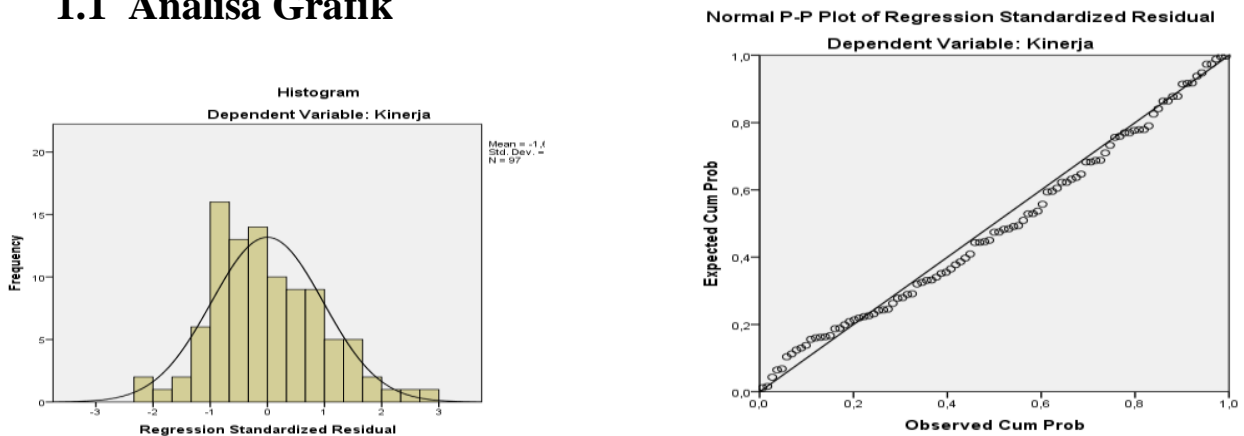

Sumber: Output SPSS 22, 2020

Gambar IV.1. Hasil Uji Normalitas Grafik Histogram dan P-P Plot 
KREATIF : Jurnal Ilmiah Prodi Manajemen Universitas Pamulang, Vol. 8, No.2, Desember 2020

Gambar IV.1 di atas terlihat bagan histogram menampilkan data tersebar normal sebab terlihat grafik histogram memberi skema sebaran yang tidak berbelok ke kiri serta ke kanan.

Grafik P-P Plots di atas membuktikan titik-titik tersebar disekeliling garis diagonal serta mengiringi garis diagonal. Maka berdasarkan hasil itu, kesimpulannya adalah residual dari model regresi itu terdistribusi normal.

\section{Analisa Statistik}

Uji normalitas residual ini dilakukan dengan menggunakan metode One-Sample Komogorov Smirnov (1-Sample-KS). Berikut hasil uji normalitas:

\section{Tabel IV.1. Hasil Uji Normalitas}

\begin{tabular}{|ll|r|}
\hline & & \multicolumn{1}{|c|}{ Unstandardized Residual } \\
\hline $\mathrm{N}$ & Mean & 97 \\
Normal & .0000000 \\
Parameters & & 1,52936715 \\
Most Extreme & Std. Deviation & Absolute \\
Differences & Positive & .063 \\
& Negative & .063 \\
Test Statistic & -.048 \\
Asymp. Sig. (2-tailed) & .063 \\
\hline
\end{tabular}

Sumber: Output SPSS 22, 2020

Hasilnya terbukti data terdistribusi normal yang diketahui dari nilai signifikan yang dihasilkan sebesar $0,200>0,05$.

\section{Uji Multikolinieritas}

Uji data tidak adanya hubungan antar variabel bebas bisa diketahui juga melalui angka Tolerance serta kebalikan Variance Inflation Factor (VIF)

Tabel IV.2. Hasil Uji Multikolinearitas

\begin{tabular}{|l|l|r|r|}
\hline \multirow{2}{*}{ Model } & \multicolumn{2}{|c|}{ Collinearity Statistics } \\
\cline { 2 - 4 } & Tolerance & \multicolumn{1}{|c|}{ VIF } \\
\hline \multirow{3}{*}{1} & (Constant) &, 614 & 1,629 \\
\cline { 2 - 4 } & Disiplin Kerja &, 444 & 2,254 \\
\cline { 2 - 4 } & Insentif &, 669 & 1,494 \\
\cline { 2 - 4 } & Komunikasi &, 426 & 2,349 \\
\cline { 2 - 4 } & Ling Kerja Fisik & & \\
\hline
\end{tabular}

Sumber: Output SPSS 22, 2020

Angka tolerance pada tabel di atas terlihat seluruh variabel independen lebih di atas 0,10 , dan juga angka VIF seluruhnya di bawah 10 . Sehingga disimpulkan model regresi tidak terindikasikan terjadi multikolinieritas.

\section{Uji Heteroskedastisitas}

\section{Metode Grafik}

Untuk memperkirakan terjadi tidaknya heteroskedastisitas dalam sebuah persamaan regresi linier berganda bisa diketahui melalui bagan scatterplot dalam output SPSS. 


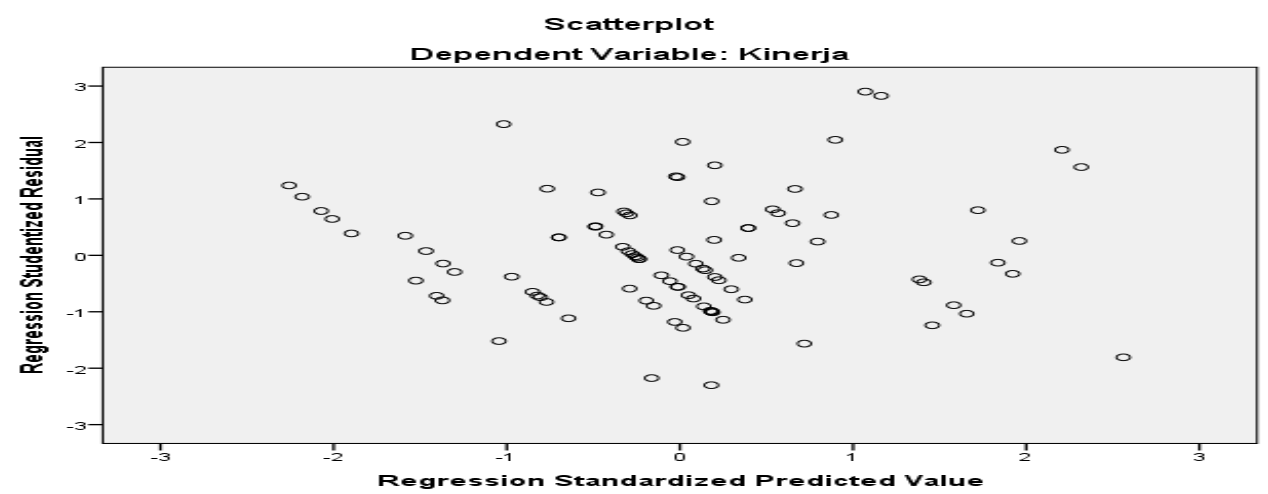

Sumber: Output SPSS 22, 2020

Gambar IV.3. Grafik Hasil Uji Heteroskedastisitas

Dari Gambar IV.3 di atas, terlihat poin-poin menyebar tidak merata serta tidak terbentuk format yang pasti di atas atau di bawah angka nol pada sumbu Y, sehingga kesimpulannya tidak ada indikasi heteroskedastisitas dalam model regresi.

\section{Uji Glejser}

Uji heteroskedastisitas memiliki tujuan untuk mengetes apakah dari bentuk regresi terindikasi perbedaan varian dari residual satu obsertasi ke observasi lain.

Tabel IV.3. Uji Heteroskedastisitas dengan Uji Glejser

\begin{tabular}{|c|c|c|c|c|c|c|}
\hline \multirow{2}{*}{\multicolumn{2}{|c|}{ Model }} & \multicolumn{2}{|c|}{ Unstandardized Coefficients } & \multirow{2}{*}{$\begin{array}{c}\text { Standardized } \\
\text { Coefficients }\end{array}$} & \multirow[b]{2}{*}{$\mathrm{I}$} & \multirow[b]{2}{*}{ Sig. } \\
\hline & & $\mathrm{B}$ & Std. Error & & & \\
\hline \multirow[t]{5}{*}{1} & (Constant) &,- 803 & 1,000 & &,- 803 & ,424 \\
\hline & Disiplin Kerja &, 061 & ,034 & ,232 & 1,807 & 074 \\
\hline & Insentif &,- 004 & ,048 &,- 014 &,- 089 & ,929 \\
\hline & Komunikasi &,- 001 & ,045 &,- 004 &,- 029 & ,977 \\
\hline & Ling Kerja Fisik & ,011 & ,034 & ,052 & ,339 & ,736 \\
\hline
\end{tabular}

a. Dependent Variable: ABS_RES

Sumber: Output SPSS 22, 2020

Hasil yang didapatkan, terlihat dalam Tabel IV.3 tersebut, hasil uji Glejser menunjukkan nilai signifikan variabel disiplin kerja, insentif, komunikasi dan lingkungan kerja fisik $>0,05$. Sehingga kesimpulan data penelitian ini tidak ada masalah Heteroskedastisitas.

\section{B. Hasil Analisis Data}

\section{Model Penelitian}

Analisis regresi berganda dipakai dalam melihat pengaruhnya disiplin kerja, insentif, komunikasi dan lingkungan kerja fisik pada kinerja karyawan di PT. Ganda Saribu Utama:

Tabel IV.5. Hasil Perhitungan Regresi Berganda

\begin{tabular}{|c|c|c|c|c|c|c|}
\hline \multirow{2}{*}{\multicolumn{2}{|c|}{ Model }} & \multicolumn{2}{|c|}{ Unstandardized Coefficients } & \multirow{2}{*}{$\begin{array}{c}\begin{array}{c}\text { Standardized } \\
\text { Coefficients }\end{array} \\
\text { Beta }\end{array}$} & \multirow[b]{2}{*}{$\mathrm{t}$} & \multirow[b]{2}{*}{ Sig. } \\
\hline & & $\mathrm{B}$ & Std. Error & & & \\
\hline & (Constant) & $-3,462$ & 1,688 & & $-2,051$ & ,043 \\
\hline & Disiplin Kerja & ,158 & ,057 & , 150 & 2,771 & ,007 \\
\hline & Insentif & ,441 & ,082 & ,344 & 5,395 &, 000 \\
\hline & Komunikasi & ,411 & ,076 & ,280 & 5,393 & ,000 \\
\hline
\end{tabular}


KREATIF : Jurnal Ilmiah Prodi Manajemen Universitas Pamulang, Vol. 8, No.2, Desember 2020

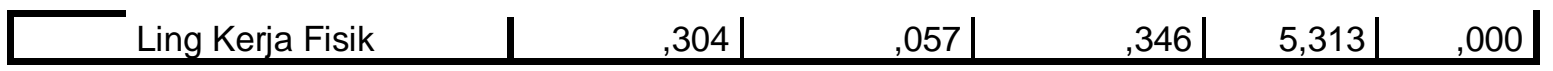

Sumber: Output SPSS 22, 2020

Berdasarkan tabel di atas bisa dibuat persamaan regresi linear berganda seperti dibawah ini:

\section{Kinerja = -3,462 + 0,158 Disiplin Kerja + 0,441 Insentif + 0,411 Komunikasi + 0,304 \\ Lingkungan Kerja Fisik}

Dari persamaan tersebut bisa dinyatakan jika :

1. Konstantanya $-3,462$, artinya apabila seluruh variabel bebas dianggap nol maka kinerja karyawan $-3,462$ satuan.

2. Seluruh koefisien regresi dari variabel independen bernilai positif yang berarti apabila terjadi peningkatan satu satuan dari masing-masing variabel independen akan menaikkan kinerja karyawan sejumlah nilai koefisien regresi masing-masing variabel independen.

\section{Koefisien Determinasi Hipotesis}

Pengujiannya bertujuan supaya tahu sebesar apa kemampuan variabel bebas menjelaskan variabel terikat. Hasil uji analisis determinasi $\left(\mathrm{R}^{2}\right)$ bisa dicermati dalam tabel IV.6:

Tabel IV.6. Hasil Uji Determinasi Model Summary

\begin{tabular}{|l|c|r|r|r|}
\hline Model & $\mathrm{R}$ & $\mathrm{R}$ Square & $\begin{array}{c}\text { Adjusted R } \\
\text { Square }\end{array}$ & $\begin{array}{c}\text { Std. Error of the } \\
\text { Estimate }\end{array}$ \\
\hline 1 &, $913^{\mathrm{a}}$ &, 834 &, 826 & 1,56226 \\
\hline
\end{tabular}

Output SPSS 22, 2020

Berdasarkan Tabel IV.6 diperoleh hasil koefisien determinasinya yaitu 0,826, yang artinya persentase variabel kinerja karyawan diterangkan dari disiplin kerja, insentif, komunikasi dan lingkungan kerja fisik senilai $82,6 \%$ dan sisanya $17,4 \%$ diterangkan variabel yang tidak dijadikan variabel di penelitian ini.

\section{Pengujian Hipotesis Secara Serempak}

Dilaksanakan uji simultan guna menguji apakah model mempunyai pengaruh simultan pada variabel terikatnya. Berikut hasil ujinya:

Tabel IV.7. Rangkuman Uji Serempak (Uji F)

ANOVA $^{a}$

\begin{tabular}{|c|c|c|c|c|c|c|}
\hline & & $\begin{array}{c}\text { Sum of } \\
\text { Squares } \\
\end{array}$ & df & Mean Square & $\mathrm{F}$ & Sig. \\
\hline \multirow[t]{3}{*}{1} & Regression & 1125,624 & 4 & 281,406 & 115,299 &, $000^{b}$ \\
\hline & Residual & 224,541 & 92 & 2,441 & & \\
\hline & Total & 1350,165 & 96 & & & \\
\hline
\end{tabular}

Sumber: Output SPSS 22, 2020

Hasil uji simultan terbukti disiplin kerja, insentif, komunikasi dan lingkungan kerja fisik berpengaruh secara bersamaan terhadap kinerja karyawan yang diperjelas dengan nilai signifikan $<0,05$.

\section{Pengujian Hipotesis Secara Parsial}


KREATIF : Jurnal Ilmiah Prodi Manajemen Universitas Pamulang, Vol. 8, No.2, Desember 2020

Untuk mengetahui pengaruh secara parsial antara variabel bebas dengan variabel terikat dilakukan uji parsial (uji t). Hasil uji parsial dirangkum dalam bentuk berikut ini:

Tabel IV.8.Hasil Uji Parsial

\begin{tabular}{|c|c|c|c|c|c|}
\hline \multirow[b]{2}{*}{ Model } & \multicolumn{2}{|c|}{$\begin{array}{c}\text { Unstandardized } \\
\text { Coefficients }\end{array}$} & \multirow{2}{*}{$\begin{array}{c}\begin{array}{c}\text { Standardized } \\
\text { Coefficients }\end{array} \\
\text { Beta }\end{array}$} & \multirow[b]{2}{*}{$t$} & \multirow[b]{2}{*}{ Sig. } \\
\hline & B & $\begin{array}{l}\text { Std. } \\
\text { Error }\end{array}$ & & & \\
\hline $1 \quad$ (Constant) & 3,462 & 1,688 & & $-2,051$ &, 043 \\
\hline Disiplin Kerja &, 158 & ,057 & 150 & 2,771 & ,007 \\
\hline Insentif & ,441 & ,082 & 344 & 5,395 &, 000 \\
\hline Komunikasi & ,411 & ,076 & ,280 & 5,393 & ,000 \\
\hline $\begin{array}{l}\text { Ling Kerja } \\
\text { Fisik }\end{array}$ & ,304 & ,057 & ,346 & 5,313 &, 000 \\
\hline
\end{tabular}

Sumber: Output SPSS 22, 2020

Tabel IV.8 menjelaskan jika disiplin kerja, insentif, komunikasi serta lingkungan kerja fisik berpengaruh pada kinerja karyawan yang dilihat dari nilai signifikansinya yang kurang dari 0,05.

\section{KESIMPULAN DAN SARA}

\section{A. Kesimpulan}

Kesimpulan yang bisa ditarik berdasarkan hasil penelitian ialah:

1) Disiplin Kerja memberikan pengaruh positif signifikan pada Kinerja Karyawan PT. Ganda Saribu Utama Medan.

2) Insentif memberikan pengaruh positif signifikan pada Kinerja Karyawan PT. Ganda Saribu Utama Medan

3) Komunikasi memberikan pengaruh positif signifikan pada Kinerja Karyawan PT. Ganda Saribu Utama Medan

4) Lingkungan Kerja Fisik memberikan pengaruh positif signifikan pada Kinerja Karyawan PT. Ganda Saribu Utama Medan

5) Disiplin Kerja, Insentif, Komunikasi Dan Lingkungan Kerja Fisik memberikan pengaruh secara serempak pada Kinerja Karyawan PT. Ganda Saribu Utama Medan.

6) Dari hasil pengujian koefisien determinasinya memperlihatkan jika $82,6 \%$ variasi variabel terikat yang bisa diterangkan oleh variabel bebas disiplin kerja, insentif, komunikasi serta lingkungan kerja fisik, sementara lainnya sebesar $17,4 \%$ d diterangkan oleh variabel diluar penelitian ini.

\section{B. Saran}

1) Perusahaan disarankan untuk memposisikan karyawan sesuai dengan keahliannya, memilih pimpinan dapat membimbing bawahannya, memposisikan karyawan sesuai dengan latar belakang pendidikan, mempromosikan karyawan yang sanggup menjalankan pekerjaan sesuai dengan keinginan perusahaan.

2) Perusahaan disarankan menambah insentif bagi karyawan yang sanggup menjalankan tugas sesuai dengan keinginan perusahaan, memberikan insentif serta hadiah bagi karyawan berprestasi

3) Perusahaan dan karyawan sebaiknya dapat lebih bersikap terbuka dalam menjalin komunikasi organisasi. 
KREATIF : Jurnal Ilmiah Prodi Manajemen Universitas Pamulang, Vol. 8, No.2, Desember 2020

4) Perusahaan disarankan untuk membuat tempat bekerja yang memberi ketenangan pekerja selama mengerjakan beban tugas yang dibebankan kepadanya.

\section{DAFTAR PUSTAKA}

Bangun, Wilson. 2012. Manajemen Sumber Daya Manusia. Erlangga, Jakarta.

Ghozali, Imam. 2016. Aplikasi Analisis Multivariate dengan Program SPSS, Badan Penerbit Universitas Diponegoro, Semarang.

Handoko, T. Hani. 2012. Manajemen Personalia dan Sumber Daya Manusia. BPFE, Jogyakarta

Hasibuan, Malayu. SP. 2016. Manajemen Sumber Daya Manusia. Bumi Aksara, Jakarta

Kartono, Kartini. 2017. Pemimpin dan Kepemimpinan, apakah kepemimpinan abnormal itu? Edisi 1. Jakarta: Rajagrafindo Persada

Mangkunegara. Anwar Prabu. 2013. Manajemen Sumber Daya Manusia Perusahaan. Cetakan Duabelas. Rosdakarya, Bandung.

Robbins, P, Stephen dan Judge A Timothy. 2014. Perilaku Organisasi. Edisi 12. Buku 2. Salemba Empat, Jakarta

Sanusi, Anwar. 2011. Metodologi Penelitian Bisnis : Disertai Contoh Proposal Penelitian Bidang Ilmu Ekonomi Dan Manajemen. Salemba Empat, Jakarta

Sedarmayanti. 2011. Sumber Daya Manusia dan Produktivitas Kerja. Mandar Maju, Bandung

Siagian, Sondang P. 2015. Manajemen Sumber Daya Manusia. Bumi Aksara, Jakarta

Sugiyono. 2012, Metode Penelitian Bisnis. Cetakan Kedua. Alfabeta, Bandung.

Sumarsan, Thomas, 2013. Sistem Pengendalian Manajemen. Indeks, Jakarta

Suranto, AW. 2011. Komunikasi Interpersonal. Graha Ilmu. Yogyakarta

Sutrisno, Edy. 2013. Budaya Organisasi. Cetakan Ketiga. Edisi 1. Kencana Prenada

Media Group, Jakarta. 